\title{
Fractionation of carbohydrate and protein content of some forage feeds of ruminants for nutritive evaluation
}

\author{
Lalatendu Keshary Das ${ }^{1}$, S. S. Kundu², Dinesh Kumar ${ }^{3}$ and Chander Datt ${ }^{2}$ \\ 1. Veterinary Dispensary, Kalampur, Kalahandi, Odisha, India; 2. Division of Dairy Cattle Nutrition, National Dairy \\ Research Institute, Karnal, Haryana, India; 3. Division of Animal Nutrition, Indian Veterinary Research Institute, \\ Izatnagar, Uttar Pradesh, India. \\ Corresponding Author: Lalatendu Keshary Das, e-mail: drlalatendu27@gmail.com, SSK: sskundu.kln@gmail.com, \\ DK: kr.dinesh7@gmail.com, CD: chandatt@gmail.com \\ Received: 24-10-2014, Revised: 09-01-2015, Accepted: 16-01-2015, Published online: 19-02-2015
}

doi: 10.14202/vetworld.2015.197-202. How to cite this article: Das LK, Kundu SS, Kumar D, Datt C (2015) Fractionation of carbohydrate and protein content of some forage feeds of ruminants for nutritive evaluation, Veterinary World 8(2)197-202.

\begin{abstract}
Aim: To evaluate some forage feeds of ruminants in terms of their carbohydrate (CHO) and protein fractions using Cornell Net Carbohydrate and Protein System (CNCPS).

Materials and Methods: Eleven ruminant feeds (six green fodders - maize, oat, sorghum, bajra, cowpea, berseem and five range herbages - para grass, guinea grass, hedge lucerne, setaria grass and hybrid napier) were selected for this study. Each feed was chemically analyzed for proximate principles (dry matter, crude protein [CP], ether extract, organic matter and ash), fiber fractions (neutral detergent fiber, acid detergent fiber, acid detergent lignin, cellulose and hemicellulose), primary $\mathrm{CHO}$ fractions ( $\mathrm{CHO}$, non-structural $\mathrm{CHO}$, structural $\mathrm{CHO}$ and starch) and primary protein fractions (neutral detergent insoluble $\mathrm{CP}$, acid detergent insoluble $\mathrm{CP}$, non-protein nitrogen and soluble protein). The results were fitted to the equations of CNCPS to arrive at various $\mathrm{CHO}$ (CA - fast degrading, $\mathrm{CB}_{1}$ - intermediate degrading, $\mathrm{CB}_{2}$ - slow degrading and $\mathrm{CC}$ - nondegrading or unavailable) and protein ( $\mathrm{PA}$ - instantaneously degrading, $\mathrm{PB}_{1}$ - fast degrading, $\mathrm{PB}_{2}$ - intermediate degrading, $\mathrm{PB}_{3}$ - slow degrading and $\mathrm{PC}$ - non-degrading or unavailable) fractions of test feeds.

Results: Among green fodders, cowpea and berseem had higher CA content while except hedge lucerne all range herbages had lower $\mathrm{CA}$ values. $\mathrm{CB}_{1}$ content of all feeds was low but similar. All feeds except cowpea, berseem, and hedge lucerne contained higher $\mathrm{CB}_{2}$ values. Oat among green fodders and hybrid napier among range herbages had lower $\mathrm{CC}$ fraction. Feeds such as bajra, cowpea, berseem and the setaria grass contained lower PA fraction. All green fodders had higher PB content except maize and cowpea while all range herbages had lower $\mathrm{PB}_{1}$ values except hedge lucerne. Para grass and hybrid napier contained exceptionally low $\mathrm{PB}_{2}$ fraction among all feeds. Low $\mathrm{PC}$ contents were reported in oat and berseem fodders.

Conclusion: Based on our findings, it was concluded that feeds with similar $\mathrm{CP}$ and $\mathrm{CHO}$ content varied significantly with respect to their $\mathrm{CHO}$ and protein fractions. Due to lower $\mathrm{CC}$ fraction, oat and hybrid napier were superior feeds in terms of CHO supply to ruminants. Similarly, among all feeds oat and berseem had a lower PC fraction, thus were considered good sources of protein for ruminants.
\end{abstract}

Keywords: carbohydrate and protein fractions, green fodders, range herbages, ruminants.

\section{Introduction}

Forages usually constitute the major portion of the ruminant feeds in our country. Due to acute shortage of concentrate feeds for animals, the livestock farming in India still relies heavily on forage feed resources [1]. Dry forages such as straw, stover, husk, etc. are nutritionally very poor and usually fulfill only the appetite of the animals. However, green forages such as fodders and range herbages are generally adequate in meeting the requirements of maintenance and moderate levels of production in ruminants. Thus, their proper nutritive evaluation is the need of the hour for their optimum utilization in low producing animals of our country. Dietary nutrients particularly carbohydrates $(\mathrm{CHO})$ and proteins are often heavily modified in rumen before their presentation to the animal

Copyright: The authors. This article is an open access article licensed under the terms of the Creative Commons Attributin License (http:// creative commons.org/licenses/by/2.0) which permits unrestricted use, distribution and reproduction in any medium, provided the work is properly cited. for real digestive processes. Knowledge of potential rumen degradability of feed fractions is key to assess their nutritive values and extent of utilization in ruminants. Conventional proximate and detergent analysis procedures do not meet these criteria. Hence, a system including above factors will be the most scientific way of feed analysis. The Cornell Net Carbohydrate and Protein System (CNCPS) as described by Fox et al. [2] seems to be the answer to the existing feed analytical limitations; because it accounts for the effects of variation due to feed $\mathrm{CHO}$ and protein fractions, their relative ruminal degradation rates and ultimately their rate of passage through the intestine. The system has been further modified to cater to the needs of present day new ruminant feeds $[3,4]$. Reports regarding fractions of various classes of Indian feeds are available. Certain forages were evaluated by research workers like Trivedi et al. [5], Kamble et al. [6] and Singh et al. [7]. But there exists huge variations among the published reports; therefore further information is needed to update the feed database of Indian origin. 
Thus, the present study was undertaken to evaluate certain forage feeds of ruminants as per CNCPS model and to assess the acceptability of this model in the preparation of balanced rations for dairy animals.

\section{Materials and Methods \\ Ethical approval}

The experimental design and plan of the present study were duly approved by the academic council of National Dairy Research Institute (NDRI), Karnal, Haryana. As there was no direct involvement of animals in the experiment, no ethical permission was required.

\section{Collection and processing of green forage samples}

Samples of green forages comprised of fodders and range herbages (maize - Zea mays, oat - Avena sativa, sorghum - Sorghum bicolor, bajra - Pennisetum typhoides, cowpea - Vigna unguiculata, berseem - Trifolium alexandrinum, para grass - Brachiaria mutica, guinea grass - Panicum maximum, hedge lucerne - Desmanthus virgatus, setaria grass - Setaria pumila and hybrid napier - Pennisetum purpureum) were collected from 2 locations: The experimental fodder farm of NDRI and Indian Grassland and Fodder research Institute. Samples (leaves and thin stem included) were thoroughly mixed and a representative amount of about $500 \mathrm{~g}$ of each feed was pooled. Samples were oven dried for $48 \mathrm{~h}$ at $60^{\circ} \mathrm{C}$ and then ground to pass through a $1 \mathrm{~mm}$ sieve in an electrically operated Willey mill. The ground samples were stored for further analyses.

\section{Chemical analyses}

Samples of forage feeds were analyzed for dry matter (DM), crude protein (CP), ether extract (EE), organic matter $(\mathrm{OM})$ and ash as per the standard procedures of AOAC [8]. Neutral detergent fiber (NDF) and acid detergent fiber (ADF) were determined by the procedures of Van Soest et al. [9]. Heat stable alpha amylase and sodium sulfite were not used in NDF determination. Both NDF and ADF were expressed exclusive of ash. Lignin was determined by solublization of cellulose with $72 \%(\mathrm{w} / \mathrm{w})$ sulfuric acid in ADF residue. The difference between ADF and lignin in the sequential analysis was the cellulose content of test feeds. Difference between NDF and ADF was the indirect measure of hemicellulose (HC).

\section{CHO fractionation}

Total CHO (\%) content was determined by subtracting CP (\%), EE (\%) and ash (\%) from 100. The non-structural CHO (NSC) content (\%) was estimated directly from the following formula: $100-[\mathrm{CP} \%+$ $\mathrm{EE} \%+\{\mathrm{NDF} \%$ - neutral detergent insoluble $\mathrm{CP}$ (NDICP)\% $\%+$ ash\%]. Difference between total $\mathrm{CHO}$ and NSC was the indirect measure of structural CHO (SC) content of test feeds. Starch estimation in the feeds was done as per the procedure of Sastry et al. [10]. Samples were extracted with ethyl alcohol, solubilized with perchloric acid and then treated with anthrone-sulfuric acid to determine the starch content colorimetrically using standard glucose. ADL ( $\%$ NDF) and starch (\% NSC) contents were computed indirectly from their DM basis values. Equations of Sniffen et al. [11] were used to calculate CNCPS CHO fractions, which classifies $\mathrm{CHO}$ contents according to degradation rate into four fractions being $\mathrm{CA}$ (sugars and organic acids), $\mathrm{CB}_{1}$ (starch and pectins), $\mathrm{CB}_{2}$ (available cell wall content) and $\mathrm{CC}$ (unavailable lignin bound cell wall content).

\section{Protein fractionation}

NDICP, acid detergent insoluble CP (ADICP), non-protein nitrogen (NPN) and soluble protein (SP) content of test feeds were estimated as per Licitra et al. [12]. ADICP fraction was assumed to be indigestible. CP of NPN origin was estimated as the difference between total CP and CP of true protein (TP) origin precipitated with 10\% trichloroacetic acid solution. Similarly, SP content was calculated as the difference between total $\mathrm{CP}$ and buffer insoluble $\mathrm{CP}$ estimated with borate phosphate buffer ( $\mathrm{pH}$ 6.7-6.8) and freshly prepared $(1 \mathrm{~g} / 10 \mathrm{ml})$ sodium azide solution. NPN (\% SP) contents of feeds were computed indirectly from their DM basis values. Equations of Sniffen et al. [11] were used to calculate CNCPS protein fractions, which classifies protein contents according to degradation rate into five fractions being PA (NPN compounds), $\mathrm{PB}_{1}$ (globulins mainly), $\mathrm{PB}_{2}$ (albumins mainly), $\mathrm{PB}_{3}$ (prolamine, cell wall protein, denatured protein) and PC (Maillard protein, lignin and tannin bound protein).

\section{Statistical analyses}

The results obtained were subjected to statistical analyses using software package SPSS version 16.0 [13]. Means were compared using one-way analysis of variance (ANOVA) test at 5\% level of significance.

\section{Results and Discussion}

\section{Chemical constituents}

Chemical constituents of forage feeds (Table-1) revealed that the DM content of all feeds was in the range of $15-20 \%$ though higher DM content was observed in range herbages. OM and ash contents in all feeds were more or less similar. Feeds of leguminous origin such as cowpea, berseem, and hedge lucerne had higher $\mathrm{CP}$ values while others had lower but similar CP contents. Average EE content was slightly higher in green fodders than range herbages while average NDF, ADF and cellulose contents were significantly higher in range herbages. Feeds of leguminous origin such as cowpea, berseem, and hedge lucerne had lower NDF contents than other feeds, just reverse of the trend observed in $\mathrm{CP}$ values. Wadhwa et al. [14] reported slightly less CP and NDF content for maize and sorghum fodder than our findings. On the contrary, the $\mathrm{CP}$ value of bajra fodder was less, and the NDF value was more than that of the present 
Table-1: Chemical constituents of roughage feeds (\% DM).

\begin{tabular}{|c|c|c|c|c|c|c|c|c|c|c|}
\hline Feeds & DM & OM & Ash & $\mathbf{C P}$ & EE & NDF & ADF & ADL & HC & Cellulose \\
\hline \multicolumn{11}{|l|}{ Green fodders } \\
\hline Maize & 14.9 & 90.8 & 9.2 & 9.8 & 1.5 & 65.4 & 35.4 & 4.6 & 30.0 & 28.7 \\
\hline Oat & 12.3 & 90.2 & 9.8 & 13.9 & 2.6 & 50.1 & 26.3 & 2.4 & 23.8 & 21.4 \\
\hline Sorghum & 18.0 & 89.9 & 10.1 & 9.9 & 1.6 & 69.0 & 40.2 & 4.6 & 28.8 & 32.6 \\
\hline Bajra & 15.9 & 91.0 & 9.0 & 8.1 & 3.1 & 62.5 & 35.0 & 5.6 & 27.5 & 26.8 \\
\hline Cowpea & 16.5 & 91.3 & 8.7 & 17.1 & 3.0 & 48.0 & 31.4 & 8.1 & 16.6 & 20.9 \\
\hline Berseem & 14.7 & 90.9 & 9.1 & 18.2 & 2.9 & 41.1 & 21.2 & 6.5 & 19.9 & 13.7 \\
\hline Average & 15.4 & 90.7 & 9.3 & 12.2 & 2.5 & 56.0 & 31.6 & 5.3 & 24.4 & 24.0 \\
\hline \multicolumn{11}{|l|}{ Range herbages } \\
\hline Para grass & 23.1 & 88.7 & 11.3 & 10.8 & 1.1 & 75.1 & 49.9 & 6.8 & 25.2 & 40.0 \\
\hline Guinea grass & 20.9 & 87.4 & 12.6 & 8.2 & 1.6 & 76.5 & 48.3 & 7.0 & 28.2 & 36.1 \\
\hline Hedge lucerne & 23.9 & 90.7 & 9.3 & 19.1 & 1.9 & 49.7 & 37.7 & 10.2 & 12.0 & 24.3 \\
\hline Setaria grass & 15.2 & 83.9 & 16.1 & 8.5 & 1.8 & 65.6 & 40.6 & 5.7 & 25.0 & 31.5 \\
\hline Hybrid napier & 25.5 & 88.8 & 11.2 & 10.9 & 1.5 & 76.3 & 47.1 & 4.3 & 29.2 & 37.7 \\
\hline Average & 21.7 & 87.9 & 12.1 & 11.5 & 1.6 & 68.6 & 44.7 & 6.8 & 23.9 & 33.9 \\
\hline
\end{tabular}

$\mathrm{DM}=$ Dry matter, $\mathrm{OM}=$ Organic matter, $\mathrm{CP}=$ Crude protein, $\mathrm{EE}=$ Ether extract, NDF=Neutral detergent fiber, ADF: Acid detergent fiber, $\mathrm{ADL}=$ Acid detergent lignin, $\mathrm{HC}=$ Hemicellulose

study. However, the values were comparable. Islam et al. [15] reported significantly lower $\mathrm{CP}$ and higher NDF value in the oat fodder, which might possibly due to higher stage of maturity during the time of study. Agza et al. [16] evaluated seven cultivars of cowpea fodder and found a mean $\mathrm{CP}$ and NDF contents of 23.9 and $44.4 \%$, respectively. Our findings were significantly different as the CP value was quite lower and the NDF value was higher, but comparable to that of above report. Mandal and Banerjee [17] evaluated nutritive value of berseem in sheep and arrived at a value of $14.5 \%$ for CP content of the berseem fodder, which was lower than our findings. However findings of Prusty et al. [18] were in conformation with present results though the NDF content was a bit higher. CP content in para and guinea grass as that reported by Raja Kishore and Parthasarathy [19] was higher than our observations while the NDF content in these grasses were reported less. Khanum et al. [20] reported lower values of $\mathrm{CP}$ for para and napier grass than present findings. As per the findings of Mutimura et al. [21], it was observed that the CP and NDF contents of hedge lucerne were less than the present findings. The chemical compositions of non-legume green fodders as reported by Datt et al. [22] were in agreement with present observations. Our study revealed that though all the feeds under consideration belong to the forage category of ruminant feeds, there exists wide variability in their nutritional quality and composition. The major factors that might have affected the nutritive value of such feeds are seasonality, species specificity, site of growth, soil characteristics etc., which are well supported by studies of Arzani et al. [23], Mahala et al. [24], Subhalakshmi et al. [25] and Teka et al. [26].

\section{Primary CHO fractions of feeds}

Total CHO content (Table-2) of all feeds was almost similar except legume feeds, which recorded lower $\mathrm{CHO}$ content because they had relatively higher $\mathrm{CP}$ content than other feeds. The NSC fraction, which represents the more digestible fraction of total $\mathrm{CHO}$ was higher in legume forages (cowpea, berseem and hedge lucerne). Among non-legume forages, higher NSC content was reported in oat and bajra. Forages with lower cell wall contents (NDF, ADF, cellulose, and $\mathrm{HC}$ ) recorded higher NSC content and forages with higher cell wall contents had higher SC content. Values for total CHO, NSC and SC of the legume forages are in constitent with that reported by Chaurasia et al. [27]. The quantity of NSC present as starch (starch as \% NSC) was higher in range herbages, while starch as \% DM was higher in green fodders. ADL (\% NDF) content among green fodders and range herbages were comparable. Starch (\% NSC) and ADL ( $\%$ NDF) content of forages varied significantly among various published reports, which was most probably due to differences in chemical constituents and the starch assay of feeds. However findings of Prusty [28] regarding primary $\mathrm{CHO}$ fractions of forage feeds were in agreement with this study, but findings of Das et al. [29] were pretty different.

\section{Primary protein fractions of feeds}

Primary protein fractions (NDICP, ADICP, NPN and SP) of forage feeds are presented in Table-3. NDICP (\% DM and \% CP) content of range herbages was higher than green fodders while ADICP (\% DM and \% CP) content was comparable between two groups of forages. ADICP content represents that fraction of feed protein, which is neither available to microbes nor to the animal in case of ruminants. Low ADICP (\% CP) content was recorded in oat and berseem than other feeds. Lower values of NPN content was reported in bajra and setaria grass. Oat, berseem and hedge lucerne contained higher SP values indicating their superior protein availability in the rumen. $\mathrm{SP}(\% \mathrm{CP})$ content in green fodders was higher than range herbages while NPN (\% SP) content in range herbages was higher. Forages like bajra, oat and berseem had lower NPN (\% SP) contents, which suggested that these feeds had higher soluble TP content. 
Table-2: Primary $\mathrm{CHO}$ fractions of roughage feeds.

\begin{tabular}{|c|c|c|c|c|c|c|c|c|}
\hline Feeds & $\begin{array}{c}\text { CHO } \\
\text { (\% DM) }\end{array}$ & $\begin{array}{c}\text { NSC } \\
\text { (\% DM) }\end{array}$ & $\begin{array}{c}\text { SC } \\
(\% \text { DM) }\end{array}$ & $\begin{array}{c}\text { NSC } \\
(\% \text { CHO })\end{array}$ & $\begin{array}{c}\text { SC } \\
(\% \mathrm{CHO})\end{array}$ & $\begin{array}{l}\text { Starch } \\
\text { (\% DM) }\end{array}$ & $\begin{array}{l}\text { Starch } \\
\text { (\% NSC) }\end{array}$ & $\begin{array}{c}\text { ADL } \\
\text { (\% NDF) }\end{array}$ \\
\hline \multicolumn{9}{|l|}{ Green fodders } \\
\hline Maize & 79.4 & 17.2 & 62.2 & 21.7 & 78.3 & 11.0 & 64.0 & 7.0 \\
\hline Oat & 73.7 & 26.6 & 47.1 & 36.0 & 64.0 & 14.4 & 54.3 & 4.8 \\
\hline Sorghum & 78.5 & 13.0 & 65.5 & 16.5 & 83.5 & 6.3 & 48.6 & 6.6 \\
\hline Bajra & 79.8 & 20.0 & 59.8 & 25.1 & 74.9 & 7.4 & 36.9 & 8.9 \\
\hline Cowpea & 71.2 & 31.5 & 39.7 & 44.3 & 55.7 & 11.2 & 35.5 & 16.9 \\
\hline Berseem & 69.8 & 33.8 & 36.0 & 48.4 & 51.6 & 9.6 & 28.5 & 15.8 \\
\hline Average & 75.4 & 23.7 & 51.7 & 32.0 & 68.0 & 10.0 & 44.6 & 10.0 \\
\hline \multicolumn{9}{|l|}{ Range herbages } \\
\hline Para grass & 76.7 & 8.1 & 68.6 & 10.5 & 89.5 & 7.5 & 93.3 & 9.0 \\
\hline Guinea grass & 77.6 & 5.3 & 72.3 & 6.8 & 93.2 & 4.5 & 84.3 & 9.1 \\
\hline Hedge lucerne & 69.7 & 29.6 & 40.1 & 42.5 & 57.5 & 11.7 & 39.6 & 20.5 \\
\hline Setaria grass & 73.5 & 10.4 & 63.1 & 14.2 & 85.8 & 7.7 & 74.2 & 8.7 \\
\hline Hybrid napier & 76.4 & 8.0 & 68.4 & 10.4 & 89.6 & 5.1 & 64.4 & 5.6 \\
\hline Average & 74.8 & 12.3 & 62.5 & 16.9 & 83.1 & 7.3 & 71.2 & 10.6 \\
\hline
\end{tabular}

$\mathrm{CHO}=$ Total carbohydrate, NSC=Non-structural carbohydrate, SC: Structural carbohydrate, DM=Dry matter, $\mathrm{ADL}=\mathrm{Acid}$ detergent lignin, NDF=Neutral detergent fiber

Table-3: Primary protein fractions of roughage feeds (\% DM).

\begin{tabular}{|c|c|c|c|c|c|c|c|c|c|c|}
\hline \multirow[t]{2}{*}{ Feeds } & \multicolumn{2}{|c|}{ NDICP } & \multicolumn{2}{|c|}{ ADICP } & \multirow[t]{2}{*}{ TP } & \multirow[t]{2}{*}{ NPN } & \multirow[t]{2}{*}{ SP } & \multirow[t]{2}{*}{ IP } & \multirow{2}{*}{$\begin{array}{c}\text { SP } \\
(\% \text { CP) }\end{array}$} & \multirow{2}{*}{$\begin{array}{c}\text { NPN } \\
(\% \text { SP) }\end{array}$} \\
\hline & \% DM & $\%$ CP & \% DM & $\%$ CP & & & & & & \\
\hline \multicolumn{11}{|l|}{ Green fodders } \\
\hline Maize & 3.2 & 32.6 & 1.5 & 15.3 & 7.5 & 2.3 & 2.8 & 7.0 & 28.6 & 82.1 \\
\hline Oat & 2.9 & 20.9 & 0.8 & 5.7 & 11.8 & 2.1 & 6.4 & 7.5 & 46.0 & 32.8 \\
\hline Sorghum & 3.5 & 35.3 & 1.5 & 15.1 & 8.0 & 1.9 & 4.3 & 5.6 & 43.4 & 44.2 \\
\hline Bajra & 2.7 & 33.3 & 1.4 & 17.3 & 7.3 & 0.8 & 2.7 & 5.4 & 33.3 & 29.6 \\
\hline Cowpea & 8.4 & 49.1 & 3.0 & 17.5 & 15.3 & 1.8 & 2.9 & 14.2 & 16.9 & 62.1 \\
\hline Berseem & 5.1 & 28.0 & 1.6 & 8.8 & 16.4 & 1.8 & 5.4 & 12.8 & 29.7 & 33.3 \\
\hline Average & 4.3 & 33.2 & 1.6 & 13.3 & 11.1 & 1.8 & 4.1 & 8.8 & 33.0 & 47.4 \\
\hline \multicolumn{11}{|l|}{ Range herbages } \\
\hline Para grass & 6.4 & 59.3 & 1.8 & 16.7 & 7.3 & 3.5 & 3.9 & 6.9 & 36.1 & 89.7 \\
\hline Guinea grass & 4.1 & 50.0 & 1.8 & 21.9 & 6.5 & 1.7 & 2.4 & 5.8 & 29.3 & 70.8 \\
\hline Hedge lucerne & 9.6 & 50.3 & 2.3 & 12.1 & 16.9 & 2.2 & 5.3 & 13.8 & 27.7 & 41.5 \\
\hline Setaria grass & 2.5 & 29.4 & 1.1 & 12.9 & 8.0 & 0.5 & 1.1 & 7.4 & 12.9 & 45.5 \\
\hline Hybrid napier & 6.7 & 61.5 & 2.0 & 18.3 & 7.6 & 3.3 & 3.9 & 7.0 & 35.8 & 84.6 \\
\hline Average & 5.8 & 50.1 & 1.8 & 16.4 & 9.3 & 2.2 & 3.3 & 8.2 & 28.4 & 66.4 \\
\hline
\end{tabular}

$\mathrm{NDICP}=$ Neutral detergent insoluble $\mathrm{CP}, \mathrm{ADICP}=$ Acid detergent insoluble $\mathrm{CP}, \mathrm{TP}=$ True protein, $\mathrm{NPN}=$ Non protein nitrogen, $\mathrm{SP}=$ Soluble protein, $\mathrm{IP}=$ Insoluble protein, $\mathrm{DM}=$ Dry matter, $\mathrm{CP}=$ Crude protein

Reports of Kamble et al. [6] and Gupta et al. [30] regarding primary protein fractions were not in agreement with our results. This was probably because of the differences in chemical composition of feeds and estimation procedures.

\section{CNCPS CHO and protein fractions}

When CNCPS CHO fractions of forage feeds (Table-4) were interpreted, it was observed that legume forages contained higher CA fraction indicating that these feeds were better sources of fermentable $\mathrm{CHO}$ to ruminants. This findings regarding legume forages were in agreement with findings of Kamble et al. [6] and Gupta et al. [30]. Para and setaria grass contained lower CA fraction. Amount of fraction $\mathrm{CB}_{1}$ was comparable between green fodders and range herbages. Sorghum and bajra among green fodders had lower $\mathrm{CB}_{1}$ content while among range herbages para and guinea grass had lower $\mathrm{CB}_{1}$ content. In typical ruminant diet, the amount of fraction $\mathrm{CB}_{2}$ is very
Table-4: CNCPS carbohydrate fractions of roughage feeds $(\% \mathrm{CHO})$.

\begin{tabular}{|c|c|c|c|c|}
\hline Feeds & CA & CB1 & CB2 & CC \\
\hline \multicolumn{5}{|l|}{ Green fodders } \\
\hline Maize & $7.8^{d}$ & $13.9^{c}$ & $64.5^{\mathrm{a}}$ & $13.8^{\mathrm{d}}$ \\
\hline Oat & $16.5^{c}$ & $19.5^{\mathrm{a}}$ & $56.1^{b}$ & $7.9^{\mathrm{e}}$ \\
\hline Sorghum & $8.5^{d}$ & $8.0^{d}$ & $69.4^{a}$ & $14.1^{\mathrm{d}}$ \\
\hline Bajra & $15.8^{\mathrm{c}}$ & $9.3^{d}$ & $58.2^{b}$ & $16.7^{c}$ \\
\hline Cowpea & $28.6^{b}$ & $15.7^{b}$ & $28.3^{c}$ & $27.4^{a}$ \\
\hline Berseem & $34.5^{a}$ & $13.7^{c}$ & $29.5^{c}$ & $22.3^{b}$ \\
\hline Average & 18.6 & 13.4 & 51.0 & 17.0 \\
\hline \multicolumn{5}{|l|}{ Range herbages } \\
\hline Para grass & $0.7^{d}$ & $9.8^{c}$ & $68.2^{\mathrm{ab}}$ & $21.3^{\mathrm{bc}}$ \\
\hline Guinea grass & $1.1^{\mathrm{d}}$ & $5.7^{\mathrm{d}}$ & $71.6^{a}$ & $21.6^{\mathrm{b}}$ \\
\hline Hedge lucerne & $25.7^{a}$ & $16.8^{\mathrm{b}}$ & $22.4^{\mathrm{d}}$ & $35.1^{\mathrm{a}}$ \\
\hline Setaria grass & $3.7^{c}$ & $10.5^{c}$ & $67.3^{\mathrm{b}}$ & $18.5^{\mathrm{c}}$ \\
\hline Hybrid napier & $10.6^{\mathrm{b}}$ & $19.2^{\mathrm{a}}$ & $59.3^{c}$ & $10.9^{d}$ \\
\hline Average & 8.3 & 12.4 & 57.8 & 21.5 \\
\hline
\end{tabular}

Means bearing different superscripts in the same column differ significantly. $(* p<0.05), C N C P S=$ Cornell Net Carbohydrate and Protein System, $\mathrm{CHO}=$ Total carbohydrate 
important as this fraction represents the available cell wall portion of ruminant feeds. Obviously legume forages contained lower $\mathrm{CB}_{2}$ fraction as these feeds are high in protein content and low in NDF content. Among other feeds, range herbages contained higher fraction $\mathrm{CB}_{2}$ than green fodders reflecting their high cell wall availability to ruminants. Fraction $\mathrm{CC}$ is the lignin bound cell wall content of a feed. Hence this fraction is indigestible both by ruminal microbes and the animal itself. Feeds with low CC fraction will be of superior quality in terms of CHO supply to ruminants and vice-versa. On this aspect, forages like oat and hybrid napier were found to be better feeds. Findings of Trivedi et al. [5] regarding various $\mathrm{CHO}$ fractions of forages though were different from our results, but they were highly comparable. On analyzing the CNCPS protein fractions of test feeds (Table-5), it was found that forages like bajra, berseem, setaria grass and hedge lucerne contained lower PA fraction, which was direct reflection of their low NPN (\% SP) values. The PC fraction is that fraction of feed $\mathrm{CP}$ which cannot be degraded by both ruminal microbes and the animal itself, thus possesses practically no feeding protein value [31]. Average PC content of range herbages were slightly more than that of green fodders. Feeds like oat and berseem had lower PC contents reflecting their high protein bioavailability. The fractions $\mathrm{PB}_{2}$ and $\mathrm{PB}_{3}$ are degraded in the rumen to a lesser extent than $\mathrm{PA}^{3}$ and $\mathrm{PB}_{1}$, thus feeds with high $\mathrm{PB}_{2}$ and $\mathrm{PB}_{3}$ content will have more by-pass protein value. All legume forages had higher $\mathrm{PB}_{2}+\mathrm{PB}_{3}$ content while among non-legume feeds maize fodder, and the setaria grass contained higher $\mathrm{PB}_{2}+\mathrm{PB}_{3}$ content. Very similar observations were made by Kamble et al. [6] and Gupta et al. [30].

\section{Conclusion}

Based on the findings of the above study it was concluded that among typical ruminant forage feeds,

Table-5: CNCPS protein fractions of roughage feeds (\% CP)

\begin{tabular}{|c|c|c|c|c|c|}
\hline Feeds & PA & PB1 & PB2 & PB3 & PC \\
\hline \multicolumn{6}{|l|}{ Green fodders } \\
\hline Maize & $23.5^{\mathrm{a}}$ & $5.1^{\mathrm{d}}$ & $38.8^{\mathrm{b}}$ & $17.3^{c}$ & $15.3^{b}$ \\
\hline Oat & $5.1^{\mathrm{c}}$ & $30.9^{a}$ & $33.1^{c}$ & $15.2^{c}$ & $5.7^{\mathrm{d}}$ \\
\hline Sorghum & $19.2^{\mathrm{b}}$ & $24.2^{\mathrm{b}}$ & $21.3^{d}$ & $20.2^{b}$ & $15.1^{\mathrm{b}}$ \\
\hline Bajra & $9.9^{d}$ & $23.4^{b}$ & $33.4^{c}$ & $16.0^{c}$ & $17.3^{\mathrm{a}}$ \\
\hline Cow & $10.5^{d}$ & $6.4^{d}$ & $34.0^{c}$ & $31.6^{a}$ & $17.5^{\mathrm{a}}$ \\
\hline $\mathrm{Be}$ & $9.9^{d}$ & $19.8^{c}$ & $42.3^{a}$ & $19.2^{\mathrm{bc}}$ & $8.8^{\mathrm{c}}$ \\
\hline Aver & 1 & 2 & 33.8 & 0 & 13.3 \\
\hline \multicolumn{6}{|l|}{ Range herbages } \\
\hline & 3 & & $6^{c}$ & $5^{a}$ & $16.7^{\mathrm{b}}$ \\
\hline & & 8 & 20 & $1^{c}$ & $21.9^{\mathrm{a}}$ \\
\hline Hedge lucerne & $11.5^{c}$ & $16.2^{\mathrm{a}}$ & $22.0^{\mathrm{b}}$ & $38.2^{\mathrm{b}}$ & $12.1^{\mathrm{c}}$ \\
\hline Setaria grass & $5.9^{d}$ & $7.0^{\mathrm{b}}$ & $57.7^{a}$ & $16.5^{d}$ & $12.9^{c}$ \\
\hline Hybrid napier & $30.3^{a}$ & $5.5^{c}$ & $4.6^{c}$ & $43.2^{\mathrm{a}}$ & $16.4^{\mathrm{b}}$ \\
\hline Average & 20.2 & 8.2 & 21.9 & 33.7 & 16.0 \\
\hline
\end{tabular}

Means bearing different superscripts in the same column differ significantly $(* p<0.05), C N C P S=$ Cornell Net Carbohydrate and Protein System, CP=Crude protein oat fodder and hybrid napier grass were better feeds of ruminants from $\mathrm{CHO}$ supply point of view while oat and berseem fodders were found to be good forage protein sources to ruminants. Maize fodder was evaluated to be a good feed with more by pass protein value. All the above feeds are extensively used in our country as forages for ruminant feeding and their preferential selection as animal forage sources are established by CNCP system. Therefore, this CNCPS model could be successfully implemented for nutritive evaluation of forage feeds of Indian origin in terms of their $\mathrm{CHO}$ and protein fractions though sufficient database should be developed before its applicability in dairy ration formulation.

\section{Authors' Contributions}

SSK and CD designed the plan of the present study. LKD and DK carried out the experimental work. Manuscript preparation along with data analysis was done by LKD. All authors read and approved the final manuscript.

\section{Acknowledgments}

The authors are thankful to the Director, NDRI, Karnal, Haryana for providing financial support for carrying out this study. The corresponding author owes his gratitude to ICAR and NDRI for providing institutional scholarship during his M.V.Sc programme at NDRI (2010-12).

\section{Competing Interests}

The authors declare that they have no competing interests.

\section{References}

1. Datta, D. (2013) Indian fodder management towards 2030: A case of vision or myopia. Int. J. Manage. Soc. Sci. Res., 2(2): 33-41.

2. Fox, D.G., Sniffen, C.J., O’Connor, J.D., Russel, J.B. and Van Soest, P.J. (1992) A net carbohydrate and protein system for evaluating cattle diets. III. Cattle requirements and diet adequacy. J. Anim. Sci., 70(11): 3578-3596.

3. Lanzas, C., Sniffen, C.J., Seo, S., Tedeschi, L.O. and Fox, D.G. (2007) A revised CNCPS feed carbohydrate fractionation scheme for formulating rations for ruminant. Anim. Feed Sci. Technol., 136(3\&4): 167-190.

4. Tylutki, T.P., Fox, D.G., Durbal, V.M., Tedeschi, L.O., Russel, J.B., Vanamburgh, M.E., Overton, T.R., Chase, L.E. and Pell, A.N. (2008) Cornell net carbohydrate and protein system: A model for precision feeding of dairy cattle. Anim. Feed Sci. Technol., 143(1\&4): 174-202.

5. Trivedi, S., Mahanta, S.K. and Kundu, S.S. (2007) Evaluation of commonly used forages for carbohydrate and protein fractions. Range Manage. Agroforestry, 28(2b): 253-255.

6. Kamble, A.B., Puniya, M., Kundu, S.S., Shelke, S.K. and Mohini, M. (2011) Evaluation of forages in terms of carbohydrate, nitrogen fractions and methane production. Indian J. Anim. Nutr., 28(3): 231-238.

7. Singh, S., Kushwaha, B.P., Nag, S.K., Mishra, A.K., Singh, A. and Anele, U.Y. (2012) In vitro ruminal fermentation, protein and carbohydrate fractionation, methane production and prediction of twelve commonly used Indian green forages. Anim. Feed Sci. Technol., 178(1\&2): 2-11.

8. AOAC. (2005) Official Methods of Analysis. $18^{\text {th }}$ ed. 
Association of Official Analytical Chemists, Virginia, USA.

9. Van Soest, P.J., Robertson, J.B. and Lewis, B.A. (1991) Symposium: Carbohydrate methodology, metabolism and nutritional implications. In dairy cattle. Methods for dietary fiber, neutral detergent fiber and non starch polysaccharides in relation to animal nutrition. J. Dairy Sci., 74: 3583-3597.

10. Sastry, V.R.B., Kamra, D.N. and Pathak, N.N. (1991) Laboratory Manual of Animal Nutrition. Centre of Advance studies, Division of Animal Nutrition. Indian Veterinary Research Institute, Izatnagar, UP, India. p116-117.

11. Sniffen, C.J., O’Connor, J.D., Van Soest, P.J., Fox, D.G and Russel, J.B. (1992) A net carbohydrate and protein system for evaluating cattle diets. II. carbohydrate and protein availability. J. Anim. Sci., 70(11): 3562-3577.

12. Licitra. G., Harnandez, T.M. and Van Soest, P.J. (1996) Standardizations of procedures for nitrogen fractionation of ruminant feeds. Anim. Feed Sci. Technol., 57: 347-358.

13. Statistical Packages for Social Sciences 16.0. (2010) SPSS Inc., Chicago, USA. II. 60606.

14. Wadhwa, M., Kaur, K., Kumar, B. and Bakshi, M.P.S (2010) Comparative evaluation of non leguminous forages as livestock feed. Indian J. Anim. Nutr., 27(1): 44-49.

15. Islam, M.N., Alam, M.R., Kabir, A.K.M.A., Das, N.G. and Khanduker, M.M. (2010) Comparative study of yield, intake, chemical composition and nutritive values of gama (Tripsacum dactyloides), oat (Avena sativa) and sorghum (Sorghum bicolor) forages. Bang. J. Anim. Sci., 39(1\&2): 657-674.

16. Agza, B., Kasa, B., Zewdu, S., Aklilu, E. and Alemu, F. (2012) Animal feed potential and adaptability of some cowpea (Vigna unguiculata) varieties in North West lowlands of Ethiopia. Wudpecker J. Agri. Res., 1(11): 478-483.

17. Mandal, L. and Banerjee, S. (2009) Evaluation of nutritive value of berseem (Trifolium alexandrinum) in Garole sheep. J. Crop Weed, 5(2): 43-44.

18. Prusty, S., Jha, N., Kundu, S.S., Bala, P.A., Kumar, A. and Datt, C. (2012) Nutritional evaluation of chicory, berseem and oat fodders in growing buffalo calves. Indian J. Anim. Nutr., 29(2): 157-160.

19. Raja Kishore, K. and Parthasarathy, M. (2009) Prediction of energy content of tropical forages and tree leaves using NRC-2001 (a TDN-based model) in ruminants. Anim. Nutr. Feed Technol., 9: 37-43.

20. Khanum, S.A., Yacoob, T., Sadaf, S., Hussain, M., Jabbar, M.A., Hussain, H.N., Kausar, R. and Rehman, S. (2007) Nutritional evaluation of various feedstuffs for livestock production using in vitro gas method. Pak. Vet. J., 27(3): 129-133.

21. Mutimura, M., Myambi, C.B., Gahunga, P., Mgheni, D.M., Laswai, G.H., Mtenga, L.A., Gahakwa, D., Kimambo, A.E. and Ebong, C. (2013) Rumen liquor from slaughtered cattle as a source of inoculums for in vitro gas production technique in forage evaluation. Agric. J., 8(4): 173-180.

22. Datt, C., Singh, N.P., Chhabra, A. and Dhiman, K.R. (2009) Nutritional evaluation of cultivated fodder crops grown under agro-climate of Tripura. Indian J. Anim. Sci., 79(11): 1143-1148.

23. Arzani, H., Sadeghimanesh, M.R., Azarniv, H., Asadian, G.H. and Shahriyari, E. (2008) Study of phonological stages effect values of twelve species in Hamadan rangelands. Iran. J. Range Desert Res., 16: 86-95.

24. Mahala, A.G., Nsahlai, I.V., Basha, N.A.D. and Mohammed, L.A. (2009) Nutritive evaluation of natural pasture at early and late rainfall season in Kordofan and Butana, Sudan. Aust. J. Basic Appl. Sci., 3: 4327-4332.

25. Subhalakshmi, B., Bhuyan, R., Sama, D.N., Sharma, K.K. and Bora, A. (2011) Effect of variety and stage of harvest on yield, chemical composition and in vitro digestibility of hybrid napier (Pennisetum purpureum x P. americanum). Indian J. Anim. Nutr., 28(4): 418-420.

26. Teka, H., Madakadze, I.C., Angassa, A. and Hassen, A. (2012) Effect of seasonal variation on the nutritional quality of key herbaceous species in semi-arid areas of Borana, Ethiopia. Indian J. Anim. Nutr., 29(4): 324-332.

27. Chaurasia, M., Kundu, S.S., Singh, S. and Mishra, A.K. (2006) Cornell net carbohydrate and protein system for nutritional evaluation of tree leaves, shrubs and grasses. Indian J. Anim. Sci., 76(1): 81-87.

28. Prusty, S. (2011) Harmonization of CNCP system for feed evaluation and rumen fermentation kinetics of buffaloes. M.V.Sc. Thesis, Division of Dairy Cattle Nutrition, National Dairy Research Institute, Karnal, Haryana, India.

29. Das, M.M., Pailan, G.H. and Kundu, S.S. (2007) Chemical composition and carbohydrate fractions of some locally available forages and concentrate feeds of Bundelkhand. Indian J. Anim. Sci., 77(11): 1173-1177.

30. Gupta, A., Singh, S., Kundu, S.S. and Jha, N. (2011) Evaluation of tropical feedstuffs for carbohydrate and protein fractions by CNCP system. Indian J. Anim. Sci., 81(11): $1154-1160$

31. Krishnamoorthy, U., Muscato, T.V., Sniffen, C.J. and Van Soest, P.J. (1982) Nitrogen fractions in feedstuffs. J. Dairy Sci., 65(2): 217-225. 